\title{
Development of Guided Inquiry - Based Module on The Topic of Solubility and Solubility Product (Ksp) in Senior High School
}

\author{
Anna Juniar \\ Chemical Education Department \\ State University of Medan \\ Medan, Indonesia \\ Corresponding email: anna.juniar@ymail.com \\ Lestari Manalu \\ Chemical Education Department \\ State University of Medan \\ Medan, Indonesia \\ Debby Masteriana \\ Mathematics Department \\ Bandung Institute of Technology \\ Bandung, Indonesia
}

\begin{abstract}
This research was done in SMA Negeri 2 Kabanjahe, which aimed to develop, standardize, and test the chemistry module on the topic of solubility and solubility product (Ksp). The research was began by choosing sylabus of curriculum 2013, and then analyzing chemistry book on the topic of solubility and solubility product (Ksp). The book which has been analyzed then was arranged in draft. Arranged module was standardized by lectures and chemistry teachers according to the questionnaire from Badan Standar Nasional Pendidikan (BSNP). The result of this research shows that developed module accepts the BSNP criterion, feasibility of content (3.52), feasibility of language (3.72), and feasibility of performance (3.66) and guided inquiry aspect (3.46) with valid and not revised criterion. Validated module was made in hard copy and tested to students XI PMIPA-4 as experiment class and XI PMIPA-2 as control class which using manual book from school. Pre-test average score of students in experiment class was 30.83 and 31.00 in control class. After teaching and learning process was done, post-test average score was increased to be 84.00 and 74.83 in control class. One tail t-test which done towards students' achievement with $t_{\text {statistics }}>t_{\text {table }}$ (3.239 > 2.001). Based on the data analysis, students' achievement of chemistry by using guided inquiry-based module is higher than students' achievement of chemistry by using school manual book.
\end{abstract}

Keywords--module, guided inquiry, solubility product

\section{INTRODUCTION}

There were many challenges appeared when curriculum 2013 was implemented in the learning process. One of the issues which is quite prominent is the quality of learning that is low when educators are only focused on the conventional teaching materials without any creativity to develop such teaching materials innovatively. Unlike the case if teachers attempt to creatively create their own teaching materials which are more interesting, varied, also in accordance with the social and cultural context of learners [1]. One of the most widely used teaching materials is the module, because it is an effective teaching material in achieving learning objectives [2].

In the implementation of curriculum 2013, one of the recommended models is guided inquiry. By teacher guidance, students get experience of conceptual discovery and active involved in solving problems that require a scientific way of thinking and work [3]. Inquiry learning is designed to bring students directly to the scientific process in a relatively short time. The results of Schelenker's research indicate that inquiry training can improve understanding of science, be productive in creative thinking and students become skilled in obtaining and analyzing original, new and valuable information [4]. Guided inquirybased learning is effective to develop students' science process skills [5].

One of the difficult chemistry topics which is taught in the XI class of high school is solubility and solubility product, because this topic has conceptual and algorithmic properties [6]. The difficulty is related to the character of chemistry such as concepts and calculations. In addition students tend to think that learning is a burden, not a hobby. This is evidenced by the observations made in SMA Negeri 2 Kabanjahe produced minimum pass value $(\mathrm{KKM})<71$.

The using of guided inquiry-based modules provides an understanding of the definitions, facts, concepts, principles 
and processes of search and concrete action, so that the learning is student-centered. Learning with guided inquirybased modules has been shown to provide good results in improving learners' achievement on functional group identification materials [7] and improving critical thinking skills [8]. So the purpose of this research is to know whether the developed inquiry-based module of solubility and solubility product can satisfy Badan Standar Nasional Pendidikan (BSNP) standard and how its implementation can improve students' learning outcomes.

\section{RESEARCH METHODOLOGY}

The type of this research is Research dan Development (R\&D) [9]. The implementation of validated module was done in SMA Negeri 2 Kabanjahe in the year academic of 2016/2017. Two sample classes were gained by random sampling, they were XI-PMIPA-4 as experiment class and XI-PMIPA-2 as control class. Pretest-Posttest Control Group Design were used in this study. Figure 1. shows the research design.

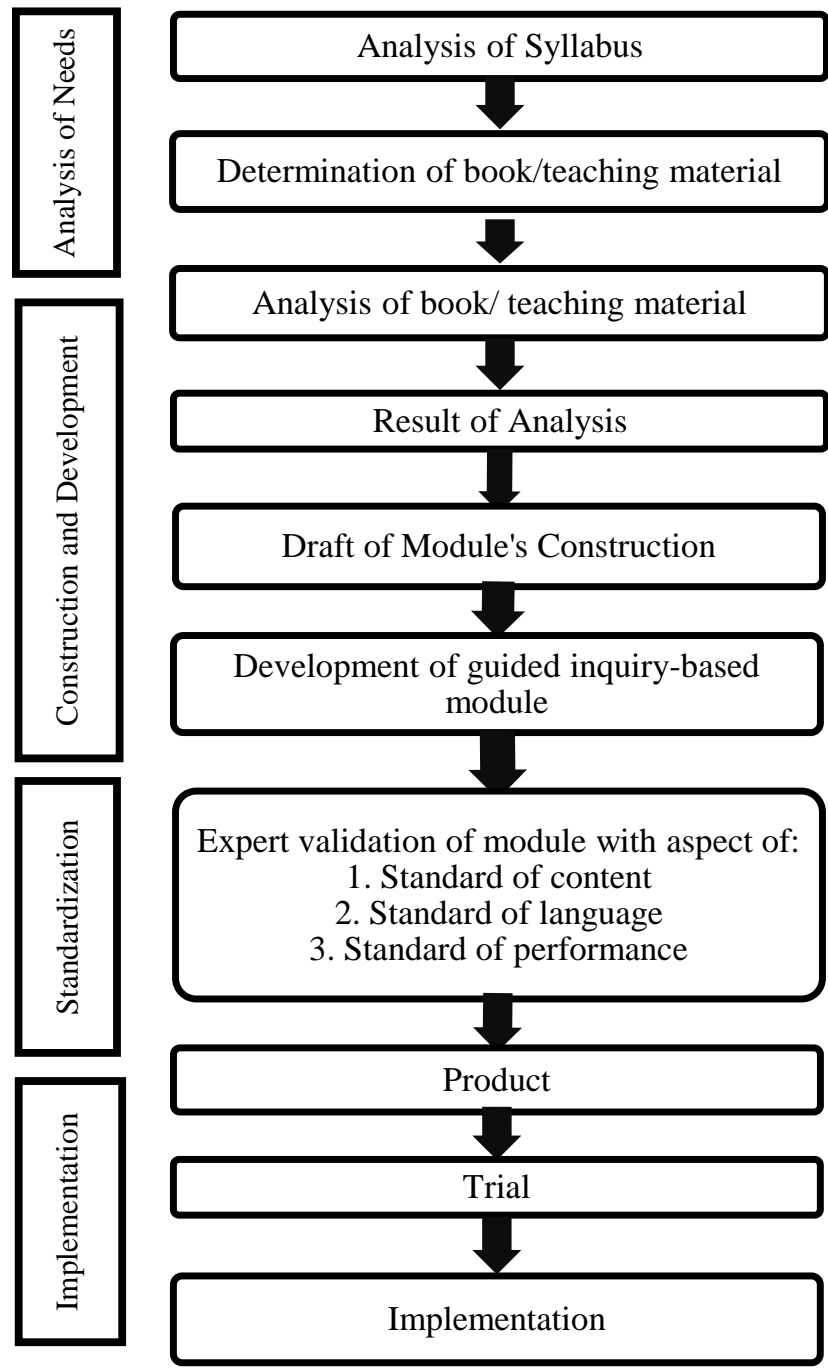

Figure 1. Research Procedure of Development of Guided Inquiry - Based Module on The Topic of Solubility and Solubility Product (Ksp)
Technique of data analysis which gained from students' learning outcomes (posttest value) was done by [10].

$$
\text { Score }=\frac{T}{N} \times 100
$$

Explanation:

$\mathrm{T}=$ the number of items being answered correctly

$\mathrm{N}=$ the number of whole items

For testing the increasing percentage of students' learning outcomes, the formula below is used:

$$
\% \mathrm{~g}=\frac{\text { posttest score- } \text { pretest score }}{\text { maximum score-pretest score }} \times 100 \%
$$

Explanation:

$\mathrm{g}<0.3=$ low,

$0.3<\mathrm{g}<0.7=$ intermediate, and $\mathrm{g}>0.7=$ high

For testing the hypothesis in both of sample classes, t-test one tail is used with formula below [11].

$$
t_{\text {statistics }}=\frac{\overline{\mathrm{X}}_{1}-\overline{\mathrm{X}}_{2}}{\sqrt{\frac{\mathrm{s}_{1}^{2}}{\mathrm{n}_{1}}+\frac{\mathrm{s}_{2}^{2}}{\mathrm{n}_{2}}}}
$$

Explanation:

$\mathrm{x}_{1}=$ average score of students' learning outcomes in experiment class

$\mathrm{x}_{2}=$ average score of students' learning outcomes in control class

$\mathrm{S}_{1}^{2}=$ deviation standard of experiment class

$\mathrm{S}_{2}{ }^{2}=$ deviation standard of control class

$\mathrm{n}_{1}=$ number of sample in experiment class

$\mathrm{n}_{2}=$ number of sample in control class

$\mathrm{t}_{\text {statistics }}=$ Value of calculated $t$. Significant level $(\alpha)=0.05$ with degree of freedom $(\mathrm{df})=\left(\mathrm{n}_{1}+\mathrm{n}_{2}\right), \mathrm{H}_{0}$ is accepted if $t_{\text {statistics }} \leq \mathrm{t}_{\text {table }}$ and $\mathrm{Ha}$ is accepted if $t_{\text {statistics }} \geq t_{\text {table }}[10]$

\section{RESULT AND DISCUSSION}

Guided inquiry-based module which has been developed was validated by expert validator, they were two chemistry lecturers in State University of Medan and one teacher in SMA Negeri 2 Kabanjahe. The result is given below.

\begin{tabular}{|c|c|c|c|c|c|c|}
\hline \multirow{2}{*}{$\begin{array}{l}\mathbf{N} \\
\text { o. }\end{array}$} & \multirow{2}{*}{ Criterion } & \multicolumn{3}{|c|}{ Assesment } & \multirow{2}{*}{ Average } & \multirow{2}{*}{$\begin{array}{c}\text { Criterion of } \\
\text { Validation }\end{array}$} \\
\hline & & $\begin{array}{c}\text { 1st } \\
\text { Lecturer }\end{array}$ & $\begin{array}{l}\text { 2nd } \\
\text { Lecturer }\end{array}$ & Teacher & & \\
\hline 1. & $\begin{array}{l}\text { Feasibility } \\
\text { of Content }\end{array}$ & 3.48 & 3.52 & 3.55 & 3.52 & $\begin{array}{l}\text { Valid, no } \\
\text { revision needed. }\end{array}$ \\
\hline 2. & $\begin{array}{l}\text { Feasibility } \\
\text { of Language }\end{array}$ & 3.62 & 3.64 & 3.90 & 3.72 & $\begin{array}{l}\text { Valid, no } \\
\text { revision needed. }\end{array}$ \\
\hline 3. & $\begin{array}{l}\text { Feasibility of } \\
\text { Performance }\end{array}$ & 3.62 & 3.79 & 3.65 & 3.66 & $\begin{array}{l}\text { Valid, no } \\
\text { revision needed. }\end{array}$ \\
\hline 4. & $\begin{array}{l}\text { Guided- } \\
\text { Inquiry } \\
\text { Aspect }\end{array}$ & 3.30 & 3.20 & 3.90 & 3.46 & $\begin{array}{l}\text { Valid, no } \\
\text { revision needed. }\end{array}$ \\
\hline
\end{tabular}

Table 1. Average Assesment Result of Guided Inquiry-based Module on The Topic of Solubility and Solubility Product (Ksp) 
Diagram in Figure 2. below shows us the average score of module standarization.

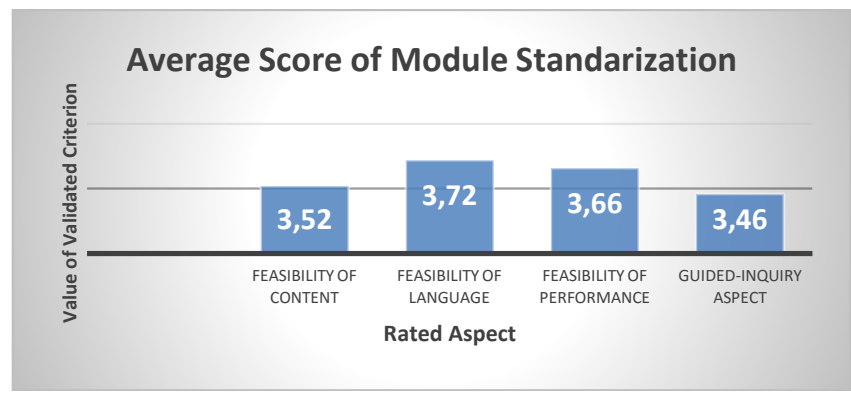

Figure 2. Average Score of Module Standarization

Students' learning outcomes which were analyzed in this research were normalized posttest score. First stage, before sample was given action, pretest was done in order to know the normality and homogeneity of initial capability in both classes. Second stage, teaching and learning process was done by using guided inquiry-based module in experiment class and manual book from school in control class. Both classes learned same topic, which was solubility and solubility product (Ksp). Based on the calculation, students' learning outcomes are summarized in Table 2. below.

Table 2. Summarize of Students' Learning Outcomes

\begin{tabular}{llcc}
\hline Data & Statistics & Experiment Class & Control Class \\
\hline Pretest & Average & 30.83 & 31 \\
& Deviation Standard & 5.34 & 5.23 \\
& Variance & 28.47 & 27.33 \\
& Minimum & 20 & 20 \\
& Maximum & 40 & 40 \\
& Sum & 925 & 930 \\
& Average & 84 & 75.83 \\
& Deviation Standard & 10.19 & 9.32 \\
& Variance & 104 & 86.80 \\
& Minimum & 70 & 55 \\
& Maximum & 100 & 95 \\
& Sum & 2520 & 2275 \\
\hline
\end{tabular}

Based on Table 2., we get the average pretest score of experiment class is 30.83 and posttest is 84 . Meanwhile, pretest score of control class is 31 and posttest is 75.83 . Based on the statistics, we can describe the average score both classes in Figure 3. below.

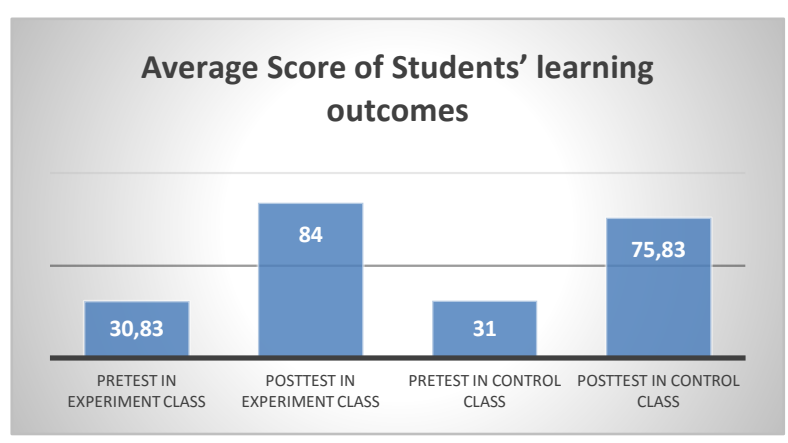

Figure 3. Average Score of Students' Learning Outcomes
The result of increasing test of students' learning outcomes (\% gain) also indicates that percentage of students' learning outcomes' in both of classes was increased. This statement is proven by average score of students' learning outcomes in experiment class was 84 and control class was 75.83 , both of them increased from the pretest score. Gain score of experiment and control class is summarized in Table 3 . below.

Table 3. Result of Normalized Gain Score in Experiment and Control Class

\begin{tabular}{|c|c|c|c|c|}
\hline Class & Criterion & Gain & $\begin{array}{c}\% \\
\text { Gain }\end{array}$ & Criterion \\
\hline Experiment & $\begin{array}{ll}\mathrm{g}<0.3 & : \text { Low } \\
0.3 \leq \mathrm{g} \leq 0.7 & : \text { Intermediate } \\
\mathrm{g}>0.7 & : \text { High }\end{array}$ & 0.772 & $77.2 \%$ & High \\
\hline Control & $\begin{array}{ll}\mathrm{g}<0.3 & : \text { Low } \\
0.3 \leq \mathrm{g} \leq 0.7 & : \text { Intermediate } \\
\mathrm{g}>0.7 & : \text { High }\end{array}$ & 0.699 & $69.9 \%$ & $\begin{array}{c}\text { Inter- } \\
\text { mediate }\end{array}$ \\
\hline
\end{tabular}

Based on Table 3., \% gain of experiment class is higher than $\%$ gain in control class that is: $77.2 \%>69.9 \%$. After testing the data analysis requirements, we knew the data is normal and homogeneous distributed, then test of hypothesis was executed. Alternative hypothesis $(\mathrm{Ha})$ is the increasing of students' learning outcomes by using guided inquiry-based module is higher than increasing of students' learning outcomes by using manual book from school. By using t-test one tail with significance level $(\alpha=0.05)$, the test of hypohesis was using the criteria if $t_{\text {statistics }}>t_{\text {table }}$ then $\mathrm{Ha}$ is accepted and Ho is rejected. Result of hypothesis test is given in Table 4 . below.

Table 4. Result of Hypothesis Test with Normalized

\begin{tabular}{clcccc}
\hline $\begin{array}{c}\text { Source of } \\
\text { Data }\end{array}$ & Class & $\mathbf{S}^{\mathbf{2}}$ & $\mathbf{t}_{\text {statistics }}$ & $\mathbf{t}_{\text {table }}$ & Explanation \\
\hline $\begin{array}{c}\text { Students' } \\
\text { Learning } \\
\text { Outcome }\end{array}$ & Experiment & 0.019 & 1.975 & 1.671 & Ha is accepted \\
\hline
\end{tabular}

Based on the calculation result, we get $t_{\text {statistics }}=1.975$ and $t_{\text {table }}=1.761$. Then, $t_{\text {atatistics }}$ is compared with $t_{\text {table }}$, then $t_{\text {statistics }}>t_{\text {table }}(1.975>1.671)$. So, Ha is accepted means the increasement of students' learning outcomes by using guided inquiry-based module is higher than manual books from school.

\section{CONCLUSION}

1. Developed module accepts the BSNP criterion, feasibility of content (3.52), feasibility of language (3.72), and feasibility of performance (3.66) and guided inquiry aspect (3.46). By those criterions, developed module satisfied valid and no revision needed.

2. The increasing of students' learning outcomes by using guided inquiry-based module is higher than the increasing of students' learning outcomes by using manual book from school. 


\section{REFERENCES}

[1] Silaban, R., Septiani, B., Hutabarat, W., (2015), Penyusunan Bahan Ajar Kimia Inovatif Materi Laju Reaksi terintegrasi Pendidikan Karakter Siswa SMA, Jurnal Tabularasa PPS UNIMED 12(1): pp 7888.

[2] Wijayanto, Zuhri, MS., (2014), Pengembangan E-Modul Berbasis Flip Book Maker Dengan Model Project Based Learning Untuk

Mengembangkan Kemampuan Pemecahan Masalah Matematika, Prosiding Mathematics and Sciences Forum: pp 625-628.

[3] Setiowati, H., Nugroho, A., Agustina, W., (2015), Penerapan Model Pembelajaran Inkuiri Terbimbing (Guided Inquiry) Dilengkapi Lks Untuk Meningkatkan Aktivitas dan Prestasi Belajar Siswa Pada Materi Pokok Kelarutan dan Hasil Kali Kelarutan Kelas XI MIA SMA Negeri 1 Banyudono Tahun Pelajaran 2014/2015, Jurnal Pendidikan Kimia (JPK) 4(4): 54-60.

[4] Torance, EP \& Safter, H.T. (1999). Making the Creative Leap and Beyond. Buffalo NY: Creative Education Foundation Press.

[5] Afiyanti, N.A., Cahyono, E. \& Soeprodjo, (2014). Keefektifan Inkuiri Terbimbing Berorientasi Green Chemistry terhadap Keterampilan Proses Sains Siswa.Jurnal Inovasi Pendidikan Kimia, VIII(1):pp 1281-88.

[6] Devetak, I., Vogrinc, J., Glazar, S.A (2009). Assesing 16-Year-Old Students' Understanding of Aqueus Solution at Submicroscopic Level, Research Science Education 39: pp 157-179.

[7] Ningsih, SS., Saputro, S., Utomo SB (2015), Pengembangan Modul Kimia Inkuiri Terbimbing Pada Materi Identifikasi Gugus Fungsi Kelas X SMK Kimia Industri, Jurnal Inkuiri 4(3): pp 51-59.

[8] Fajariyah, N., dan Haryono, (2016), Penerapan Model Inkuiri Terbimbing Untuk Meningkatkan Kemampuan Berpikir Kritis dan Prestasi Belajar Pada Materi Kelarutan dan Hasil Kali Kelarutan Siswa Kelas XI SMA Al Islam 1 Surakarta Tahun Ajaran 2014/2015 Jurnal Pendidikan Kimia (JPK) 5(2):pp 89-97.

[9] Borg, W.R \& Gall, M.D. (1983). Educational Research: An Introduction, New York: Longman.

[10] Silitonga, P.M. (2013), Swtatistik Teori dan Aplikasi dalam Penelitian, FMIPA UNIMED, Medan.

[11] Sudjana, (2005), Metode Statistika. PT. Trasito Bandung. 